\title{
Adapting to climate change: water distribution in BBA City, Algeria
}

\author{
AYOUB ZEROUAL ${ }^{1,2}$, MOHAMED MEDDI ${ }^{1}$ \& ALI A. ASSANI ${ }^{2}$ \\ 1 Higher National School of Hydraulics, Blida, R.L GEE, Algeria \\ 2 Environmental Sciences Department, University of Quebec at Trois-Rivières, Quebec, Canada \\ zeroualayoub34@yahoo.fr
}

For over 20 years, the eastern Algeria region has had significant rainfall deficits that resulted in severe droughts, which seriously affected the availability of water for drinking. Owing to considerations of affordability, drinking water is systematically underpriced because water is essential for life. Such a low price results in water being used inefficiently. This research presents the impact that a high leakage level in the water distribution network has on the water service price in BBA (Bordj Bou Arréridj) city and expected future water resources management scenarios in BBA watersheds by taking into account to the river flow simulated by GR2M using the outputs of climate models with emissions scenarios A1 and A1B. The analysis of the results shows a large economy can be made with regard to water losses, reaching up to $47 \%$ saving of the produced water volume; also, BBA city is expected to experience water stress before 2030 . 